\title{
Multicarrier SPWM Control Techniques for Three Phase Eleven Level Diode Clamped Multilevel Inverter and Hybrid Inverter with Reduced Number of Components
}

\author{
N. Susheela, P. Satish Kumar \\ Department of Electrical Engineering, University College of Engineering (A), Osmania University, India
}

\begin{tabular}{|c|c|}
\hline Article Info & ABSTRACT \\
\hline Article history: & A comparative analysis of three phase eleven level Diode Clamped \\
\hline & Multilevel Inverter (DCMLI) and hybrid inverter is performed in this paper \\
\hline Received Jun 9, 2018 & in which the later requires fewer carrier signals, less number of devices and \\
\hline Revised Aug 20, 2018 & gate drive circuits. The performance is evaluated using Phase Disposition \\
\hline Accepted Sep 7, 2018 & $\begin{array}{l}\text { (PD), Alternate Phase Opposition Disposition (APOD) and Carrier } \\
\text { Overlapping (CO) Sinusoidal Pulse Width Modulation (SPWM) methods. }\end{array}$ \\
\hline Keywords: & $\begin{array}{l}\text { The hybrid multilevel inverter has superior features over diode clamped } \\
\text { multilevel inverters and is more efficient since the positive levels of the }\end{array}$ \\
\hline Diode Clamped Inverter & inverter that are generated by high frequency switches (level generation part), \\
\hline Hybrid inverter & $\begin{array}{l}\text { are reversed by low frequency switches (polarity generation part) when the } \\
\text { voltage polarity is required to be changed for negative polarity. Therefore, }\end{array}$ \\
\hline Induction motor & the overall cost and complexity of the hybrid inverter are greatly reduced \\
\hline Pulse Width Modulation & particularly for higher inverter output voltage levels. Simulation is performed \\
\hline Total Harmonic Distortion & $\begin{array}{l}\text { for three phase eleven level diode clamped multilevel inverter and hybrid } \\
\text { multilevel inverter using MATLAB/Simulink for induction motor load and } \\
\text { the total harmonic distortion is evaluated at different load torques. }\end{array}$ \\
\hline
\end{tabular}

Copyright $@ 2018$ Institute of Advanced Engineering and Science. All rights reserved.

\section{Corresponding Author:}

N. Susheela,

Department of Electrical Engineering,

University College of Engineering (A),

Osmania University, Hyderabad-500007, Telangana, India.

Email: nsusheela2007@yahoo.com

\section{INTRODUCTION}

The multilevel inverters have drawn tremendous interest in high power high voltage applications due to their merits such as reduced voltage stress on devices, lower switching losses, lower EMI problems and less THD. The neutral point clamped inverter was proposed by Nabae [1]. The basic concept of multilevel inverter is to synthesize a staircase voltage waveform from several lower voltage DC sources which approaches the sinusoidal wave with reduced harmonic distortion [2]. In multilevel inverters, the semiconductors are wired to form series type connection so that the operation at higher voltages is possible. The switching losses and the switching frequency can be reduced by staggering the switching because the switches are not truly series connected. Conventional multilevel inverters include diode clamped inverter, flying capacitor inverter and cascaded H-bridge inverter [3], [4]. The major drawback of multilevel inverters is the higher number of power semiconductor switches required that complicates the overall system [5-9]. A multilevel inverter implemented with hybrid topology has many advantages as the levels increase when compared to conventional multilevel inverters. The hybrid multilevel inverter eliminates the diodes and capacitors that are used in DCMLI, capacitors used in flying capacitor inverters and also reduces the semiconductor switches and carrier signals required than in cascaded inverters, diode clamped, and flying capacitors inverters. An approach of utilizing high-power devices with low-switching-frequency reduces voltage distortion of output but has got current harmonics which is a major drawback. There are 
asymmetrical methods of using different values of voltage source which requires more number of power switches and diodes with different rating. Some topologies suffer from the capacitor balancing problems [10-14]. Whereas in case of hybrid multilevel inverter, the voltage sources used have equal values and has many advantages compared with conventional methods. It uses less number of switches and carrier waves and also operates the switching devices at line frequency which results in more efficiency [15-17]. In this paper PD, APOD and CO SPWM methods are utilized to drive the three phase diode clamped multilevel inverter and hybrid multilevel inverter.

\section{ELEVEN LEVEL DIODE CLAMPED MULTILEVEL INVERTER}

The three phase eleven level diode clamped multilevel inverter is implemented using carrier based sinusoidal pulse width modulation techniques for eleven level to verify the performance of the inverter. In an eleven level diode clamped multilevel inverter the switches are arranged into ten pairs. When one switch of the pair is turned ON, the other switch of the same pair must be OFF. Each switch pair works in complimentary mode and the diodes are used to provide access to mid-point voltage. At any point of time ten switches are triggered to achieve desired voltage level. The DC bus voltage is split into eleven voltage levels by using ten series connection of DC capacitors. For a DC bus voltage $\mathrm{V}_{\mathrm{dc}}$, the voltage across each capacitor is $\mathrm{V}_{\mathrm{dc}} / 10$ and voltage stress on each device is limited to $\mathrm{V}_{\mathrm{dc}} / 10$ through clamping diodes. The middle point of the ten capacitors ' $\mathrm{N}$ ' can be defined as the neutral point. Carrier waveforms for three phase eleven level diode clamped multilevel inverter are presented in Figure 1 to Figure 3 for PD, APOD and CO SPWM methods.

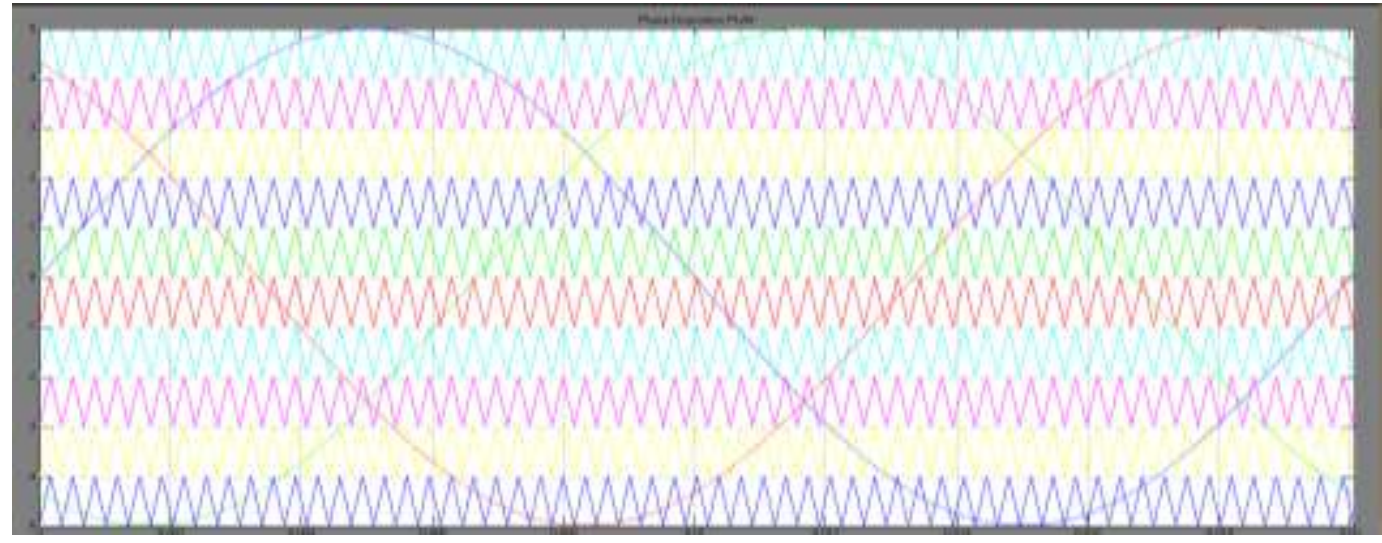

Figure 1. PD method for three phase eleven leven diode clamped multilevel inverter

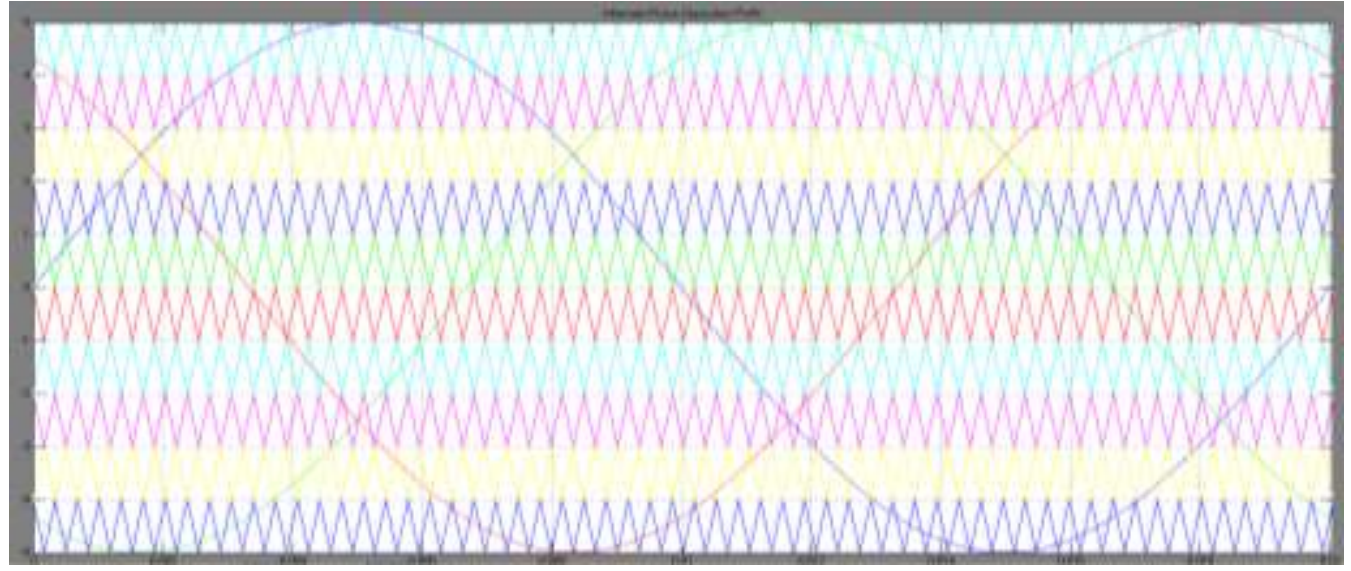

Figure 2. APOD method for three phase eleven leven diode clamped multilevel inverter 


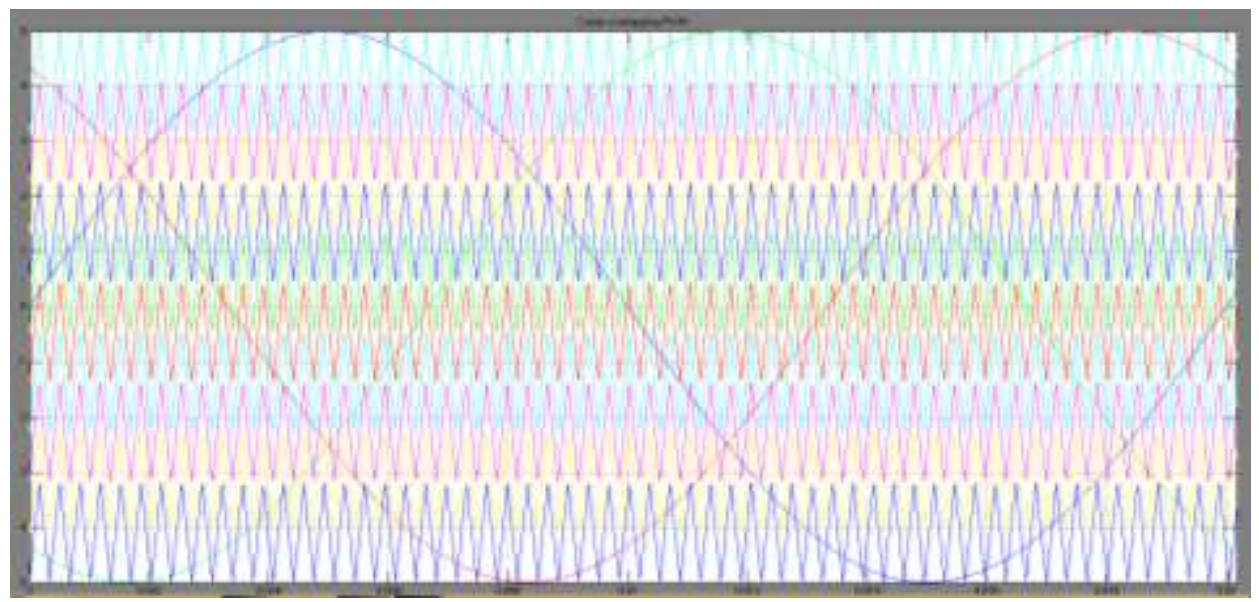

Figure 3. CO method for three phase eleven leven diode clamped multilevel inverter

Ten saw-tooth waveforms for carrier and a sinusoidal reference signal for modulator are required for diode clamped multilevel inverter in order to produce eleven levels by sinusoidal pulse width modulation technique. Higher number of clamping diodes are required as the number of level increases in case of diode clamped multilevel inverters. Also, the capacitor voltage unbalance complicates the control of the system. The diode clamped multilevel inverters needs large number of power semiconductor switches and associated gate drive circuits. In order to mitigate the aforementioned drawbacks, hybrid multilevel inverter is implemented.

\section{ELEVEN LEVEL HYBRID MULTILEVEL INVERTER}

The output voltage of hybrid multilevel inverter is separated into level generation part that utilizes high frequency switches to produce required levels in positive polarity and polarity generation part which requires low frequency switches that are responsible to generate polarity of output voltage. The level generation part and polarity generation part together helps in producing required multilevel output voltage. Whereas, in diode clamped multilevel inverters, many of the power semiconductor switches are involved for generating the levels in the output voltage in positive and negative polarities. Compared to the diode clamped multilevel inverters where all the switches are responsible for generation of bipolar levels, hybrid multilevel inverter eliminates more number of power semiconductor switches.

The sinusoidal pulse width modulation method for eleven level diode clamped multilevel inverter requires ten carriers, but five carriers are sufficient in hybrid inverter. Figure 4 shows an eleven level hybrid multilevel inverter for one phase leg. Fourteen switches and five isolated sources which are equally rated are needed for one phase leg of an eleven level hybrid multilevel inverter. The output voltage levels are generated by level generation part without polarity and the output voltage polarity is decided by the polarity generation part. Then, the output voltage required will be transferred to the output according to output polarity required. When the voltage polarity required to be changed for negative polarity, the voltage direction is reversed. For the supply voltage $\mathrm{Vdc}$, the six levels which are generated by level generation part are $0, \mathrm{Vdc} / 5,2 \mathrm{Vdc} / 5,3 \mathrm{Vdc} / 5,4 \mathrm{Vdc} / 5, \mathrm{Vdc}$. By using the polarity generation part, positive levels are converted into negative polarity (i.e., $\mathrm{Vdc} / 5,2 \mathrm{Vdc} / 5,3 \mathrm{Vdc} / 5,4 \mathrm{Vdc} / 5$, $\mathrm{Vdc}$ are converted to $-\mathrm{Vdc} / 5,-2 \mathrm{Vdc} / 5$, $-3 \mathrm{Vdc} / 5,-4 \mathrm{Vdc} / 5,-\mathrm{Vdc}$ ) as per the requirement of output polarity. Therefore, the required eleven levels are generated using the hybrid multilevel inverter. 


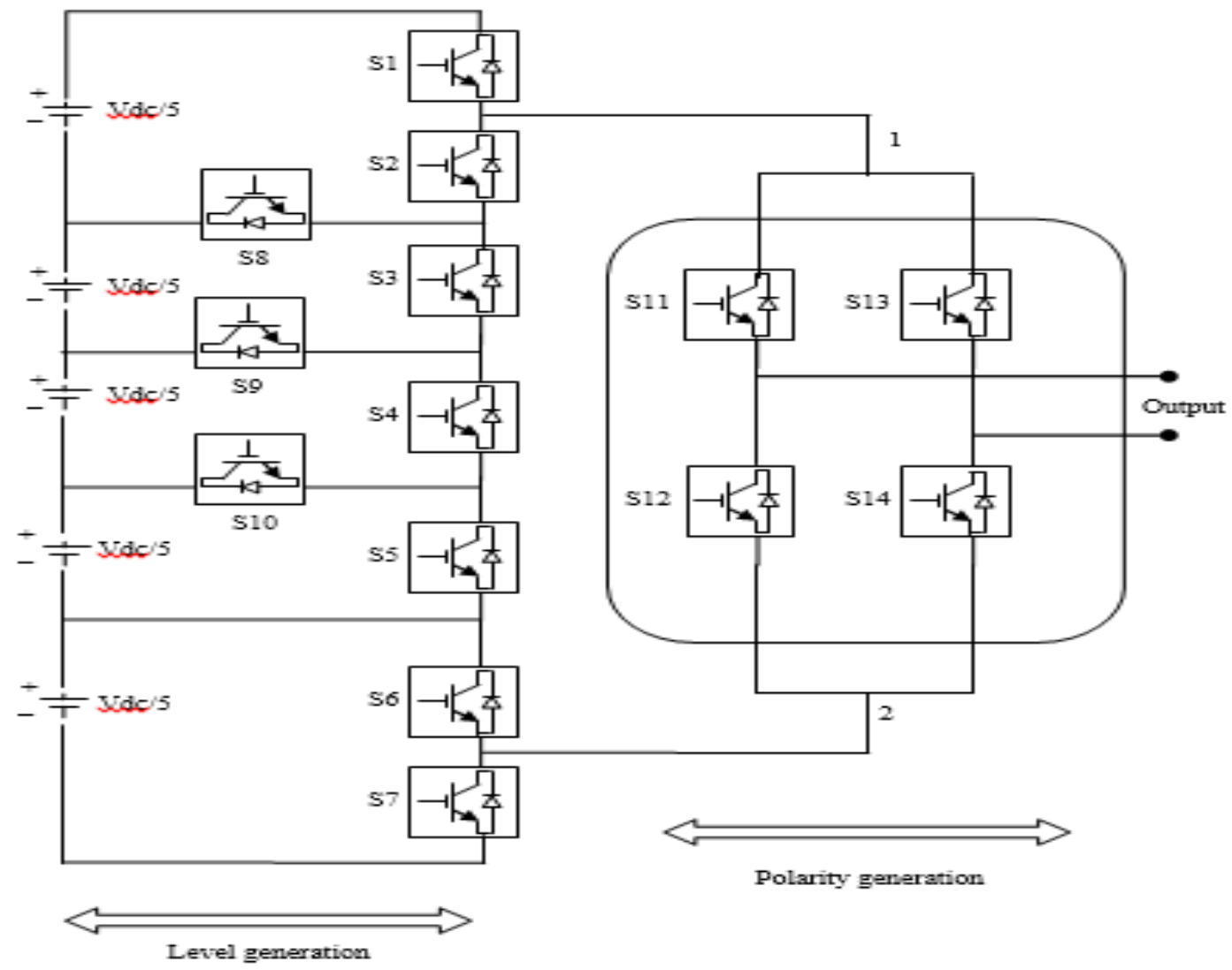

Figure 4. Structure of eleven level hybrid inverter for one phase leg

Hybrid inverter requires fewer components and half of the carriers compared to diode clamped inverter for sinusoidal pulse width modulation controller. Level generation part of hybrid inverter generates six levels and then these voltage levels will be reversed by using polarity generation part when the voltage polarity required to be changed for negative polarity. Complexities of capacitor balancing are not faced by the hybrid inverter because of fixed dc voltages. Polarity generation part works in forward and reverse modes. In Figure 4 the switches S11 and S14 will conduct in forward mode for positive output voltage polarity whereas S12 and S13 conducts in reverse mode for negative output voltage polarity. Hence, the output polarity is determined by the polarity generation part. The hybrid multilevel inverter doesn't require generation of negative pulses for negative cycle control. However, the polarity generation part performs this task while level generation part produces the number of levels required. Based on the requirement of output voltage, these levels are translated to positive or negative. In order to generate the required levels for eleven level hybrid multilevel inverter, the switching modes are shown in Table 1.

Table 1. Switching States for Eleven -Level Hybrid Inverter

\begin{tabular}{ccccccc}
\hline Mode & 0 & 1 & 2 & 3 & 4 & 5 \\
\hline 1 & S2, S3, S4, S5, S6 & S2, S3, S4, S5, S7 & S2, S3, S4, S10, S7 & S2, S3, S9, S7 & S2, S8, S7 & S1, S7 \\
2 & & S2, S3, S4, S10, S6 & S2, S3, S9, S6 & S2, S8, S6 & S1, S6 & \\
\hline
\end{tabular}

It describes the switch according to Figure 4 that should be turned $\mathrm{ON}$ to generate the required voltage level. The inverter is controlled by ten possible switching patterns. The switching mode selection should be such that during each mode transfer, less switching transients occur and also reduced switching power dissipation. By this, unwanted voltage levels during switching cycles can be avoided. The switching patterns (S2-S3-S4-S5-S6), (S2-S3-S4-S5-S7), (S2-S3-S4-S10-S7), (S2-S3-S9-S7), (S2-S8-S7) and (S1-S7) are shown in Figure 5 for producing 0 to 5 levels in the output voltage. 

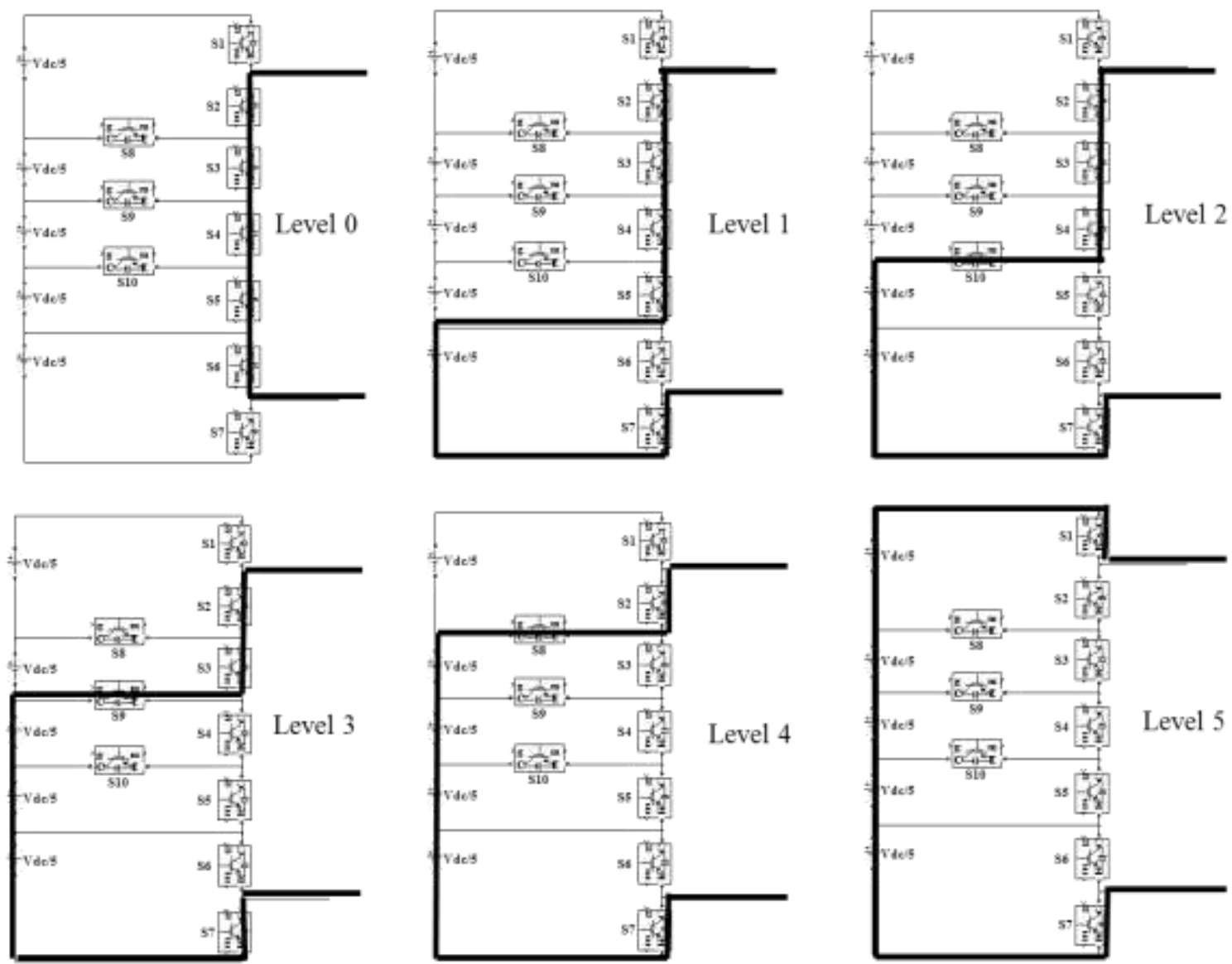

Figure 5. Switching sequence of eleven level hybrid multilevel inverter

For hybrid inverter, the modulator and five carriers for PD, APOD and CO SPWM methods are shown in Figure 6 and Figure 8. In order to meet the voltage requirements, five states are considered with certain switching patterns. To determine the overall converter efficiency, the number of switches that are required in the current path, plays an important role. Compared to conventional multilevel inverters, less number of switches are required in the hybrid multilevel inverter for conducting the circuit current which results in more efficiency. The number of power semiconductor switches required for multilevel inverters is the most important part that defines the control complexity and reliability.

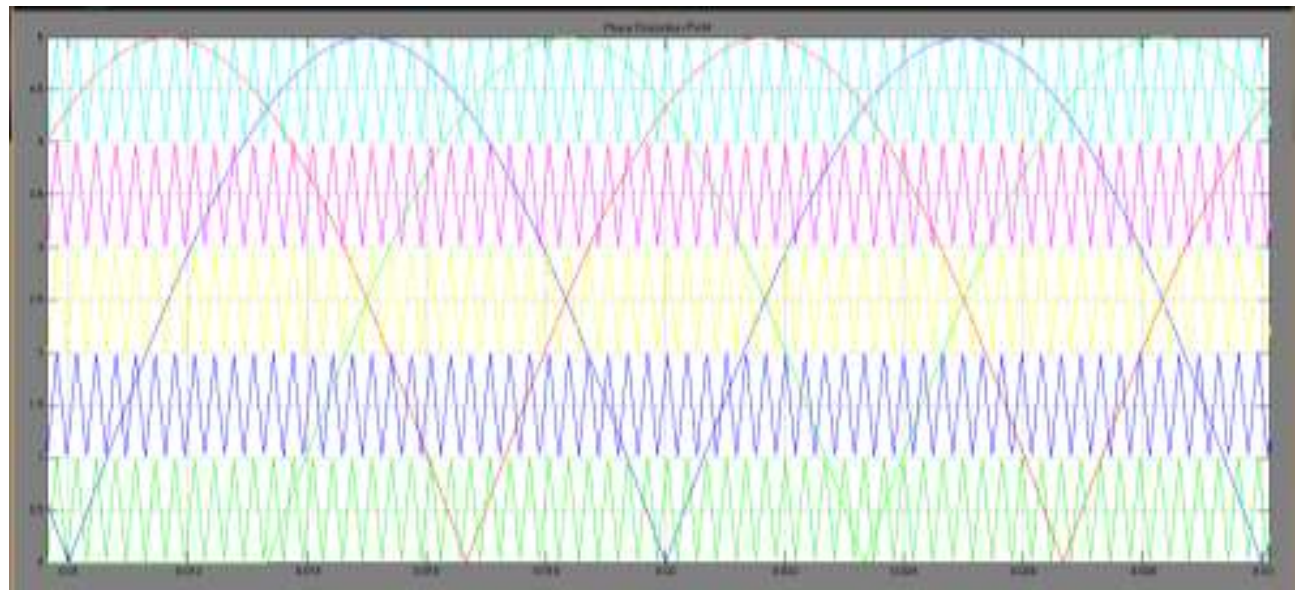

Figure 6. PD method for three phase eleven leven hybrid multilevel inverter 


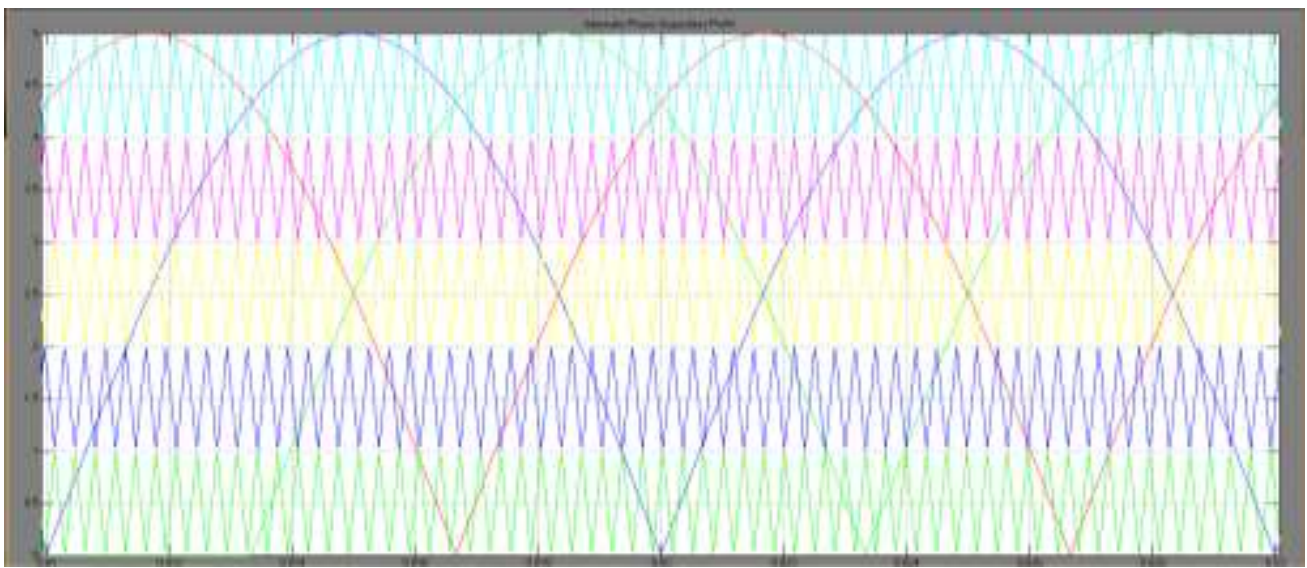

Figure 7. APOD method for three phase eleven leven hybrid multilevel inverter

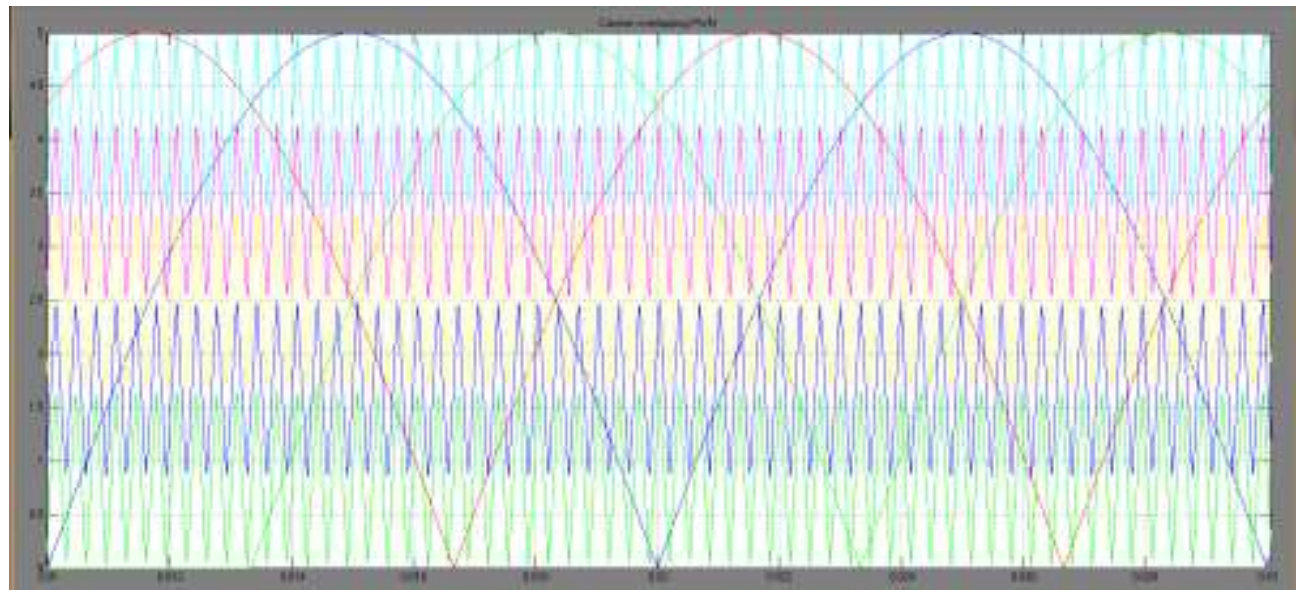

Figure 8. CO method for three phase eleven level hybrid multilevel inverter

The components required in hybrid multilevel inverter is lower than diode clamped inverter. Therefore, hybrid multilevel inverter requires reduced number of switches and less carrier signals compared to diode clamped multilevel inverter for implementation of pulse width modulation techniques

\section{RESULTS AND ANALYSIS}

For enhancement of output voltage and minimizing THD, phase disposition and alternate phase opposition disposition carrier based PWM methods are performed. The results of three phase eleven level diode clamped multilevel inverter and hybrid multilevel inverter are shown from Figure. 9 to Figure 21 for induction motor load. A squirrel cage induction motor used for diode clamped inverter and hybrid inverter has the following parameters: Nominal Power $=10 \mathrm{Hp}$, poles $=4$, rms voltage $=400 \mathrm{~V}$, frequency $=50 \mathrm{~Hz}$, speed $=1500 \mathrm{rpm}$, stator resistance $\mathrm{Rs}=0.7384 \Omega$, stator leakage inductance Lls $=3.045 \mathrm{mH}$; rotor resistance $\mathrm{Rr}^{\prime}=0.7402 \Omega$, rotor leakage inductance $\mathrm{Llr}^{\prime}=3.045 \mathrm{mH}$; mutual inductance $\mathrm{Lm}=0.1241 \mathrm{H}$, inertia $\mathrm{J}=0.07 \mathrm{kgm}^{2}$. The total input voltage of the three phase eleven-level hybrid multilevel inverter is 440 volts dc (5 isolated dc sources of each 88 volts). The frequency of the switches used in polarity generation part is $50 \mathrm{~Hz}$ and $3 \mathrm{KHz}$ in level generation part.

\subsection{Eleven level diode clamped multilevel inverter using PD, APOD and CO methods}

The results of three phase diode clamped multilevel inverter fed induction motor for eleven level are shown in Figure 9 and Figure 10 using phase disposition method. 


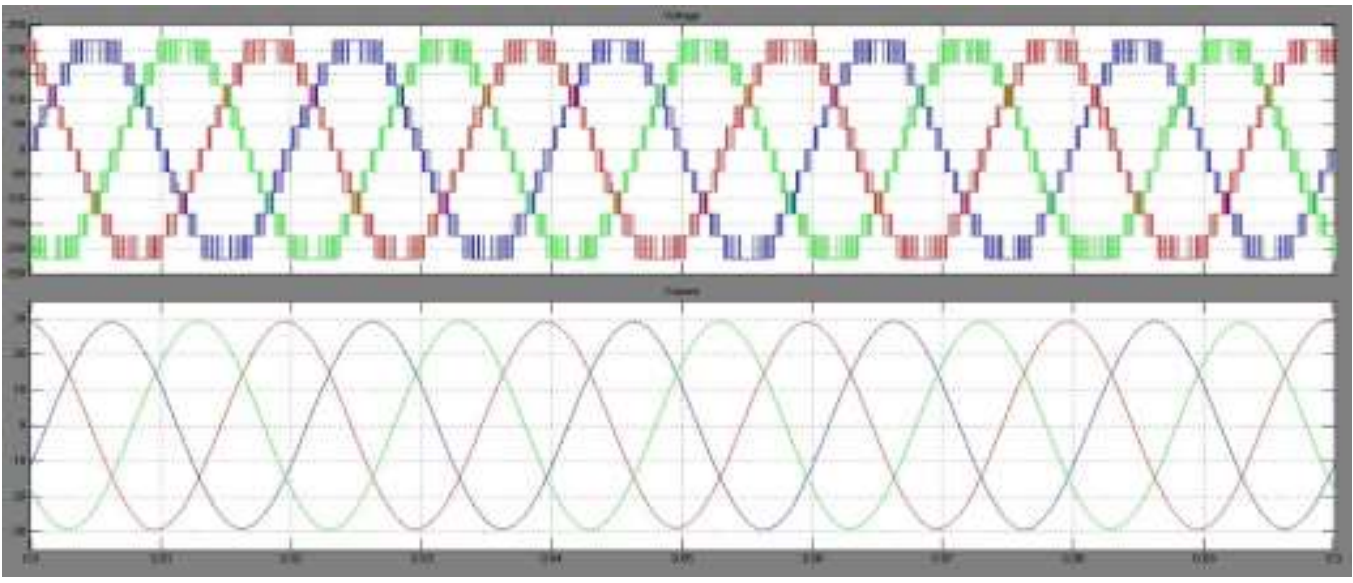

Figure 9. Waveforms of voltages and currents using PD method for DCMLI

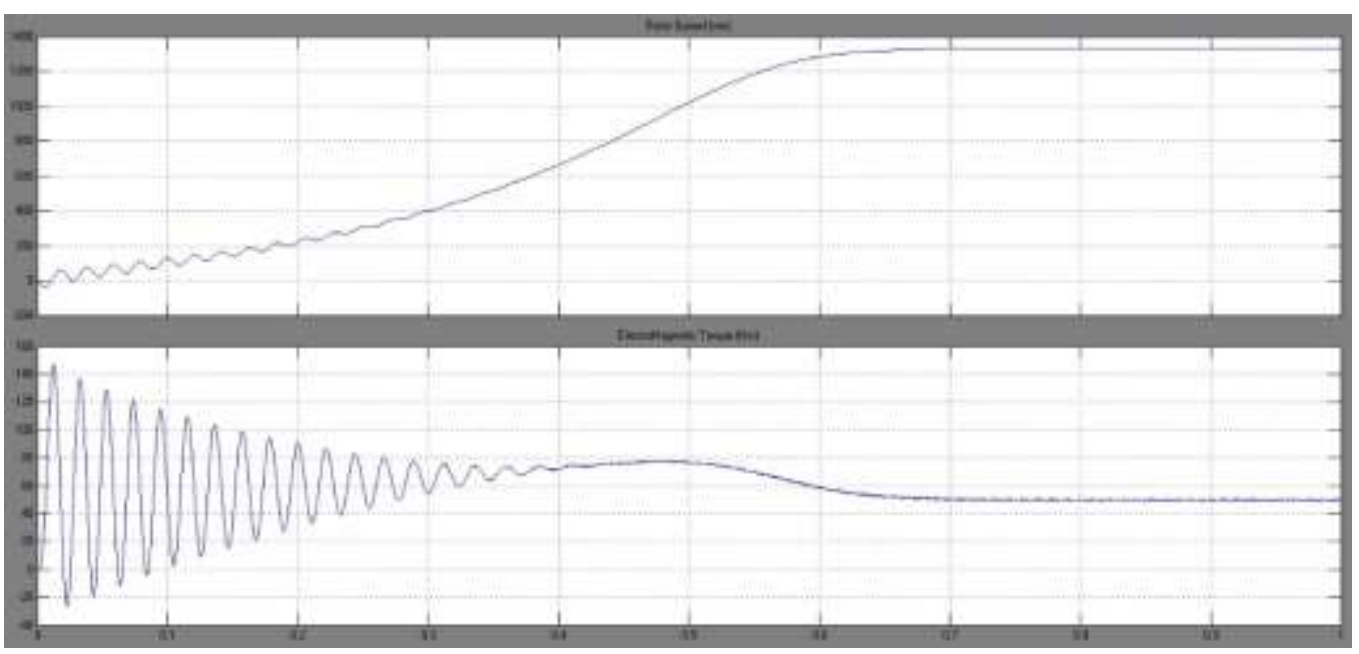

Figure 10. Speed and torque response using PD method for DCMLI

Figure 11 and Figure 12 shows the results of alternate phase opposition disposition method implemented for eleven level diode clamped multilevel inverter using induction motor load.

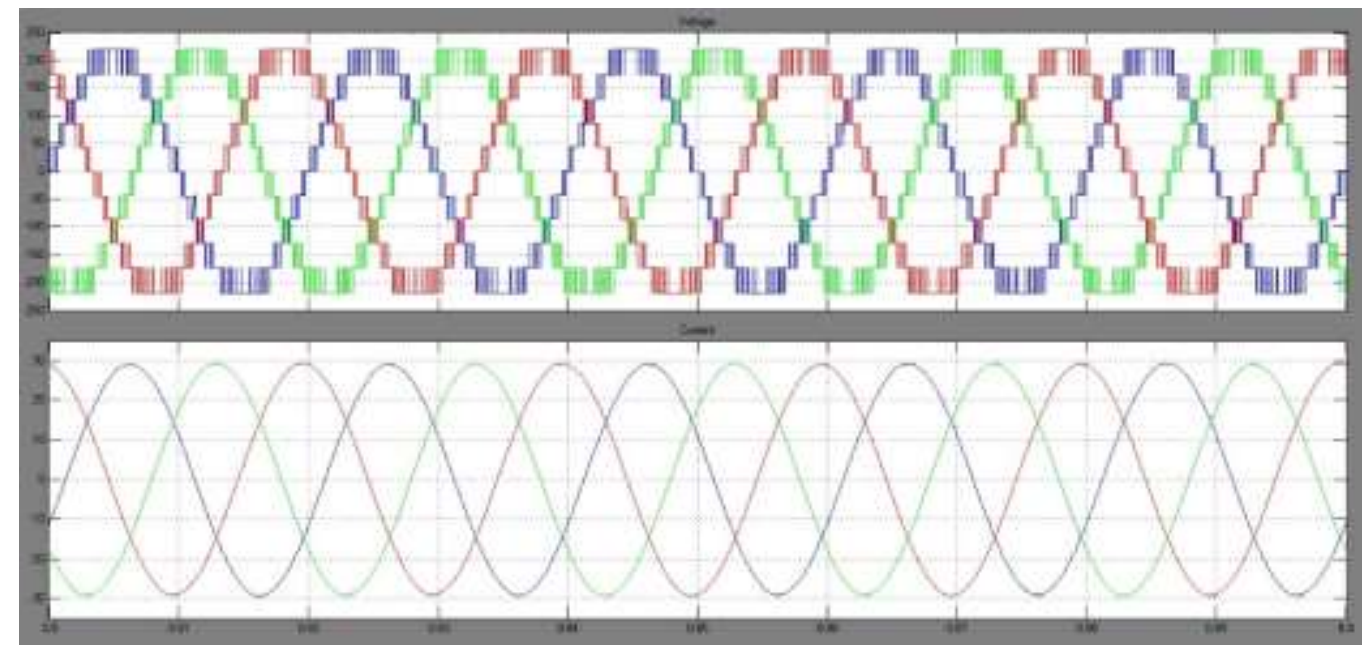

Figure 11. Waveforms of voltages and currents using APOD method for DCMLI 


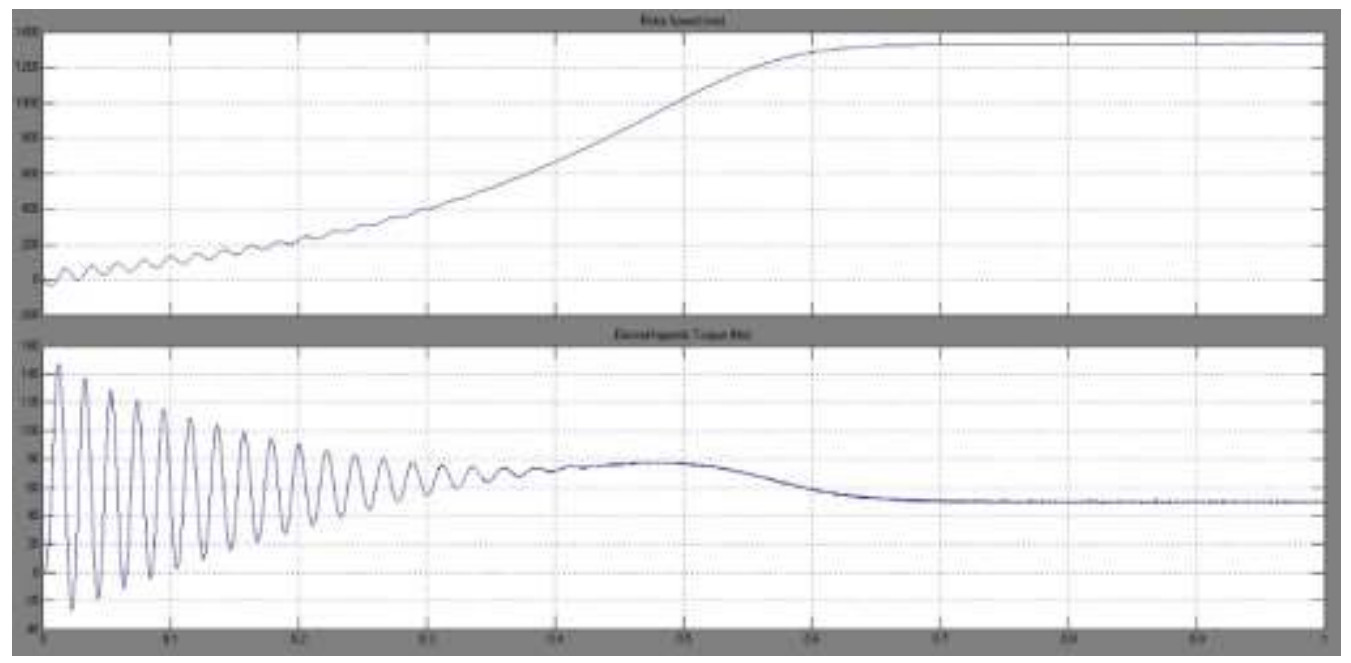

Figure 12. Speed and torque response using APOD method for DCMLI

Figure 13 and Figure 14 presents the results obtained for carrier overlapping technique for eleven level diode clamped multilevel inverter fed induction motor.

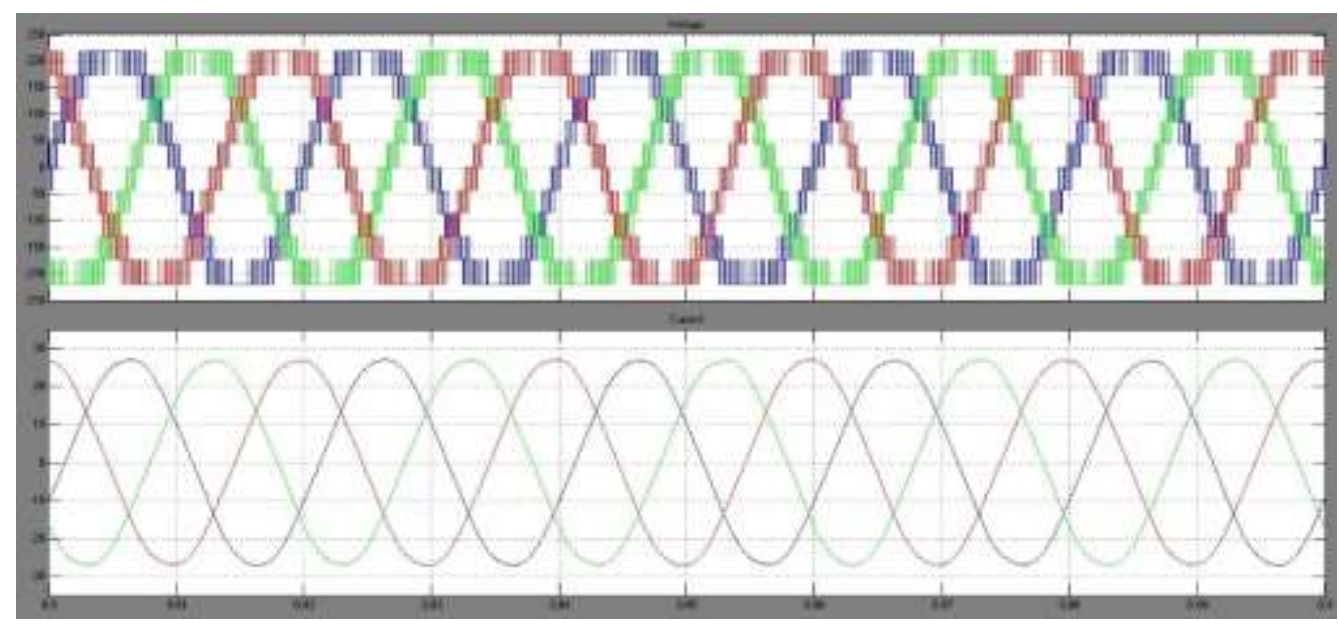

Figure 13. Waveforms of voltages and currents using CO method for DCMLI

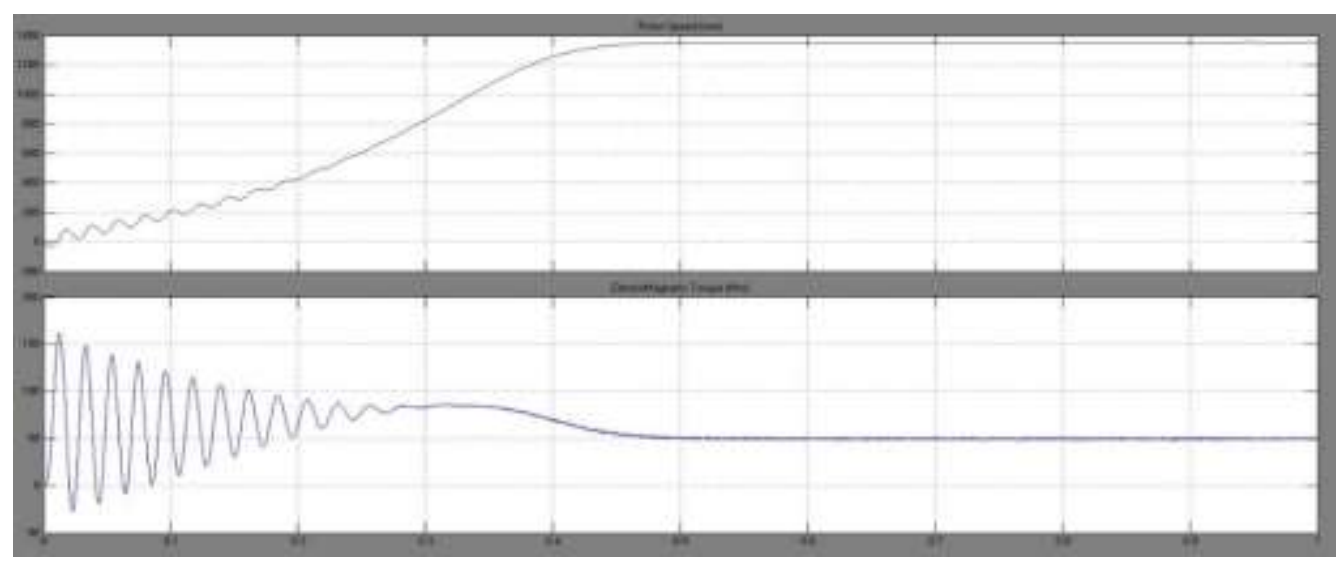

Figure 14. Speed and torque response using CO method for DCMLI 


\subsection{Eleven level hybrid inverter using PD, APOD and CO methods}

The output voltage waveform for level generation part of eleven level hybrid multilevel inverter using phase disposition method is shown in Figure 15 that is responsible for generating required levels in positive polarity. Based on the required output polarity, the polarity generation part will transfer the required level to the output. The phase disposition method is implemented for three phase eleven level hybrid inverter fed induction motor and the results are shown in Figure 16 and Figure 17. Figure 18 and Figure 19 presents the waveforms of alternate phase opposition disposition method implemented for three phase eleven level hybrid multilevel inverter fed induction motor.

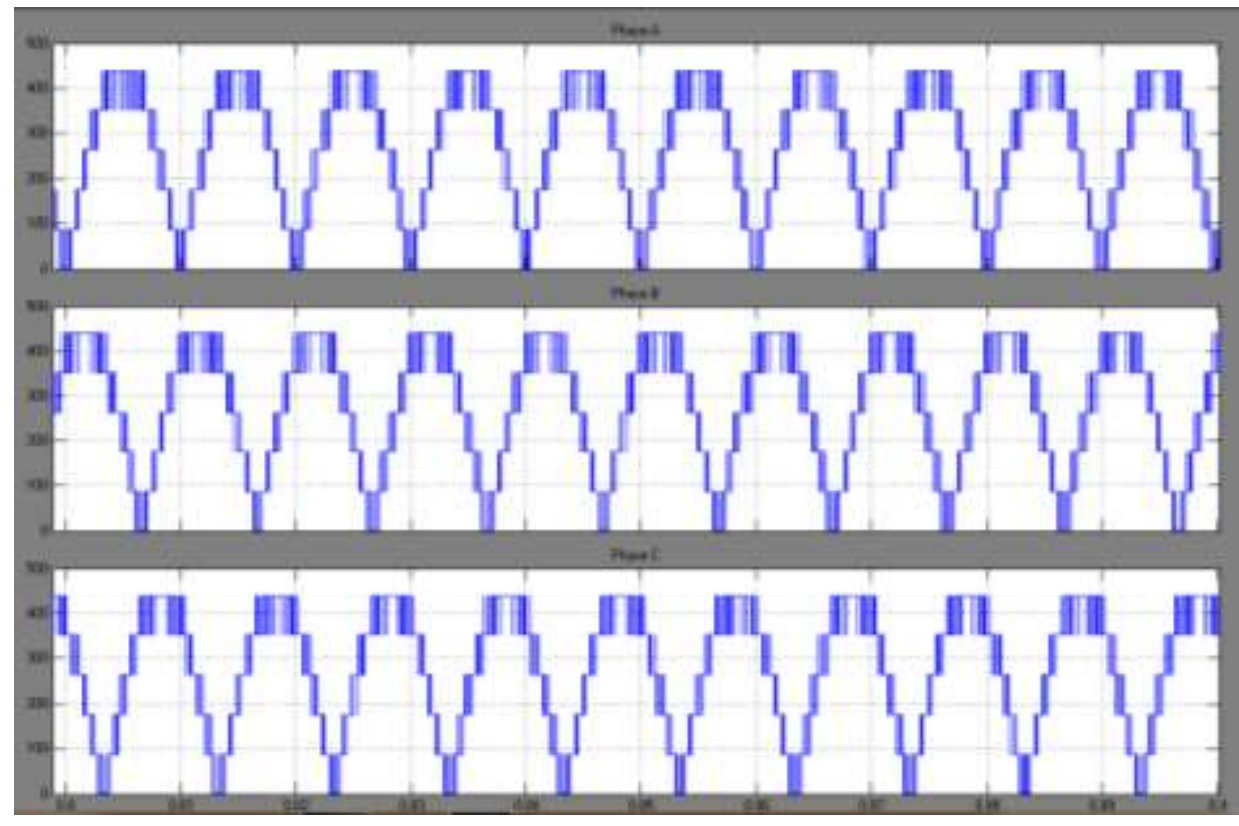

Figure 15. Output voltage waveform for level generation part of eleven level hybrid multilevel inverter

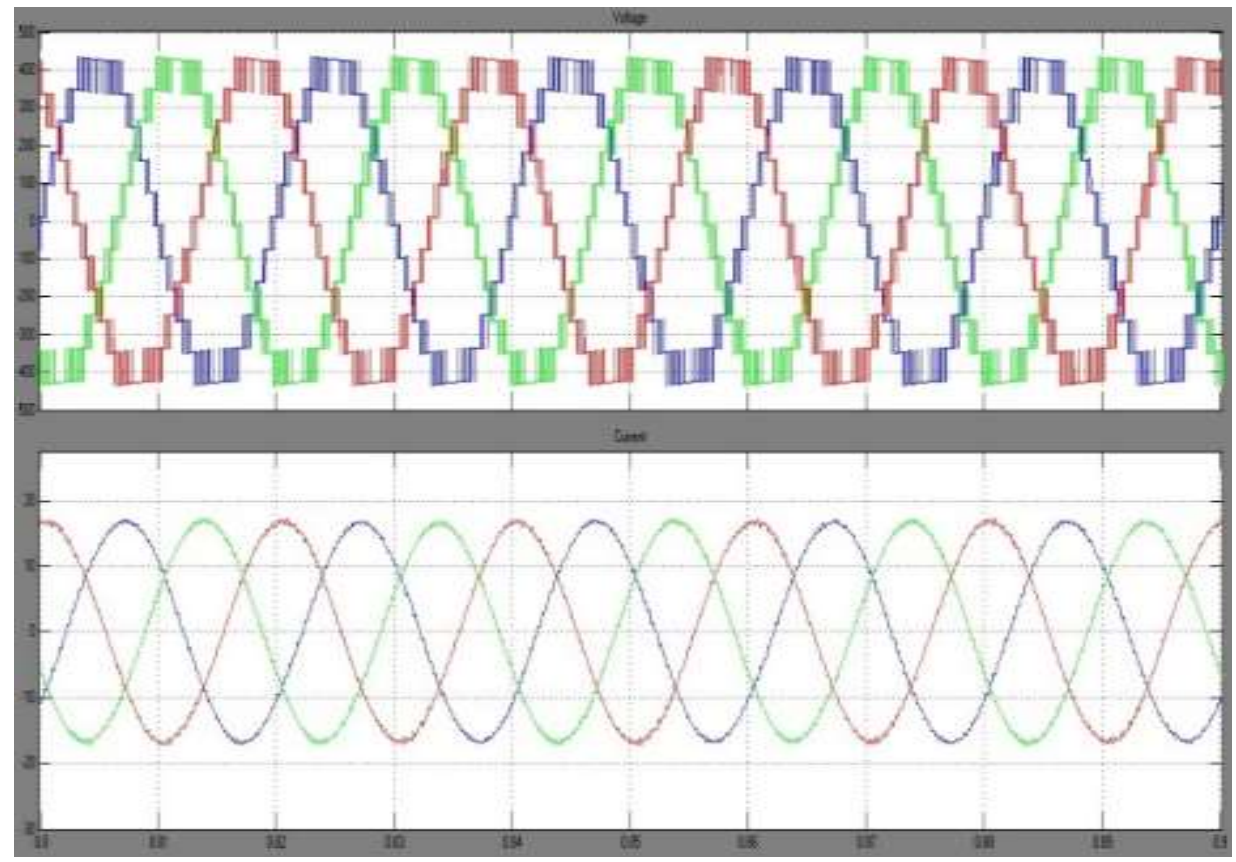

Figure 16. Waveforms of voltages and currents for hybrid inverter using PD method 


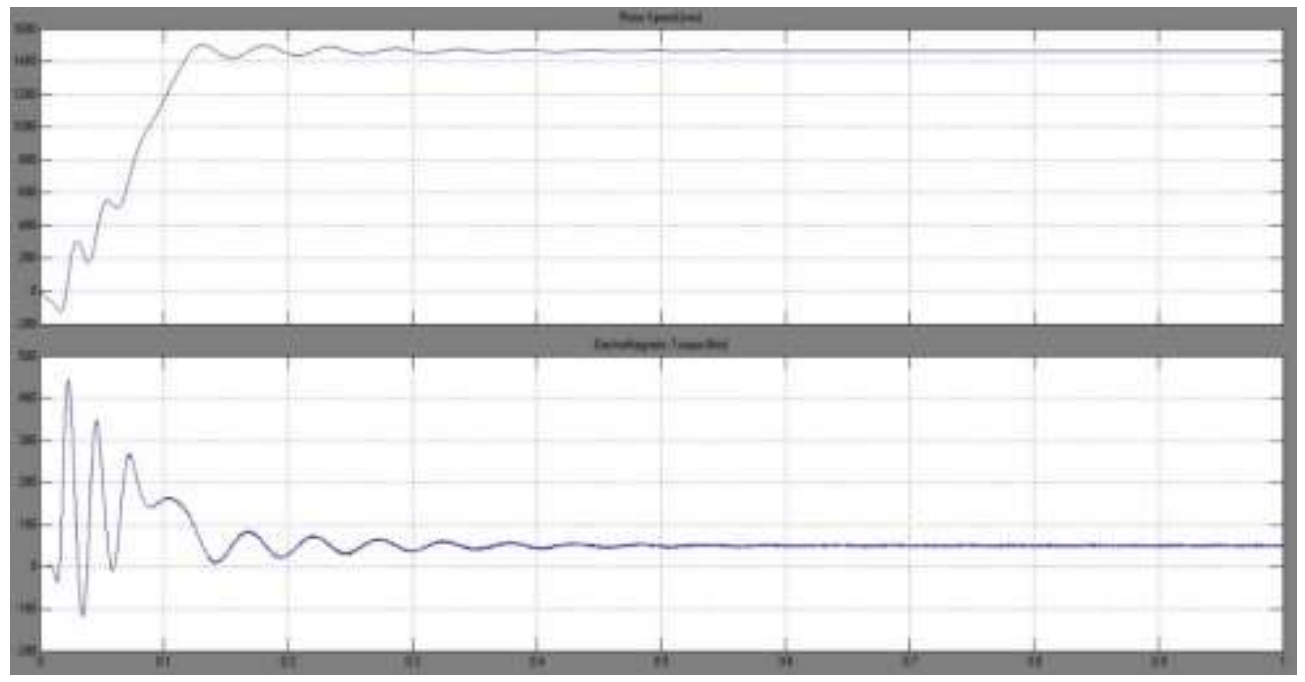

Figure 17. Speed and torque response for hybrid inverter using PD method

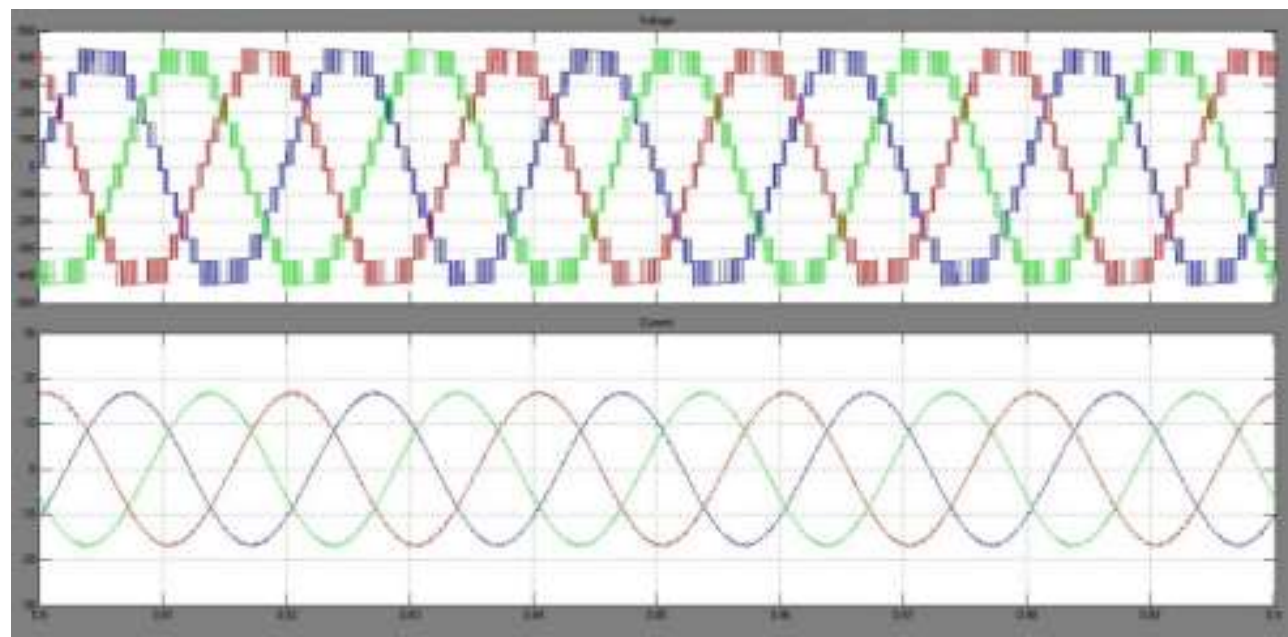

Figure 18. Waveforms of voltages and currents for hybrid inverter using APOD method

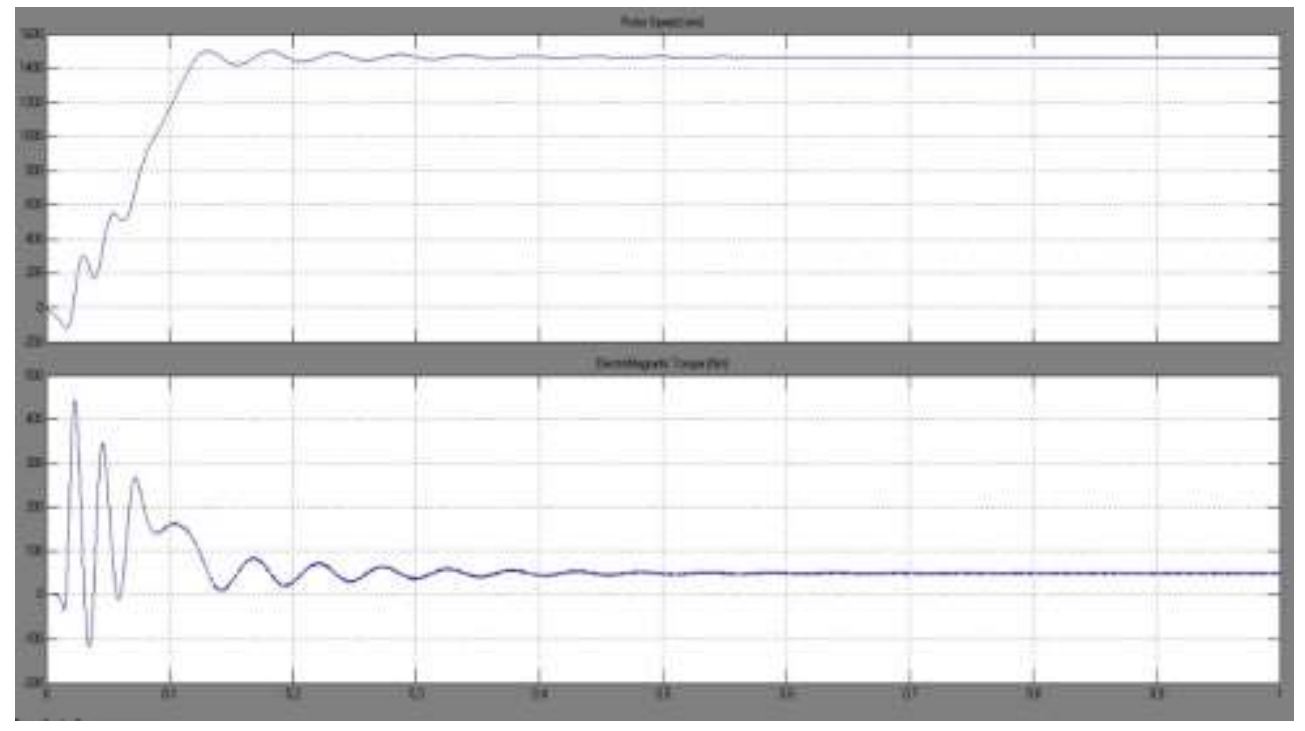

Figure 19. Speed and torque response for hybrid inverter using APOD method 


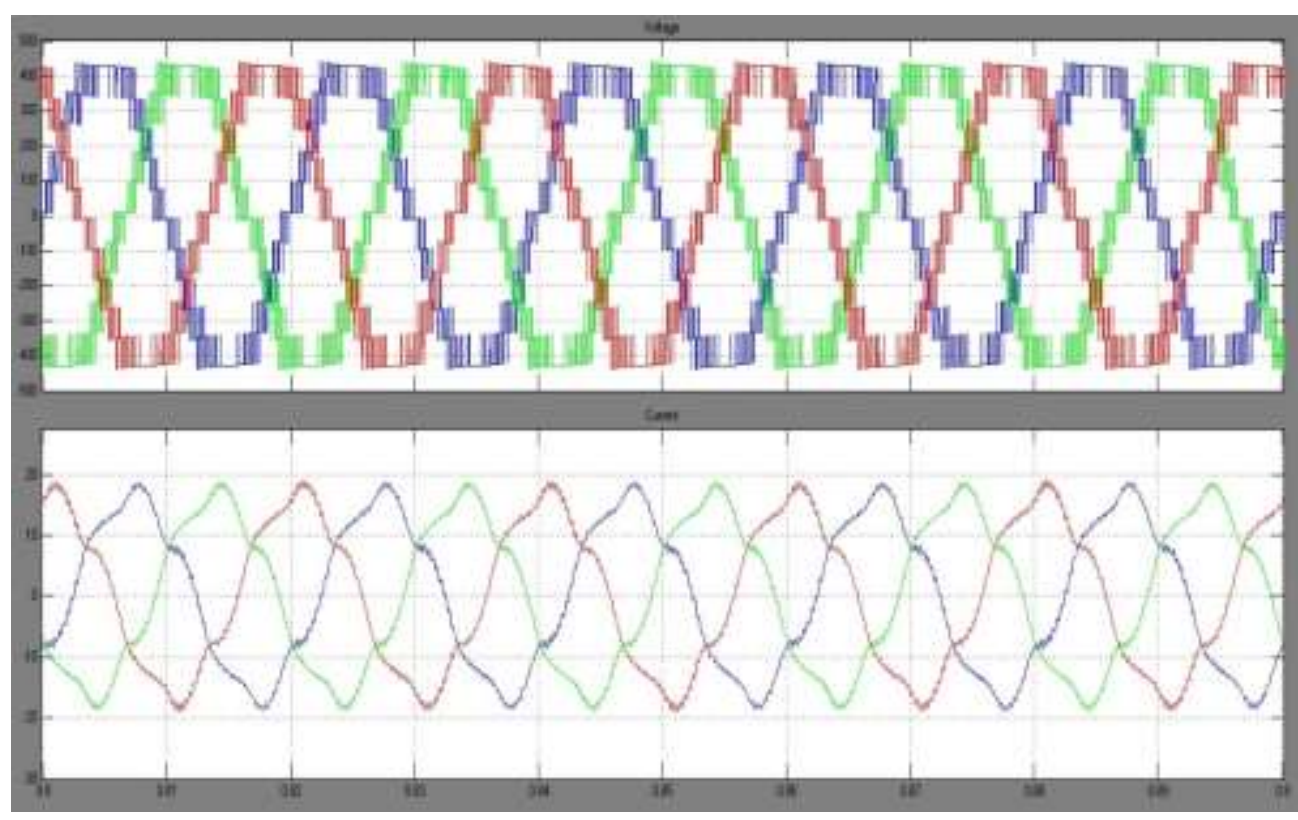

Figure 20. Waveforms of voltages and currents for hybrid inverter using CO method

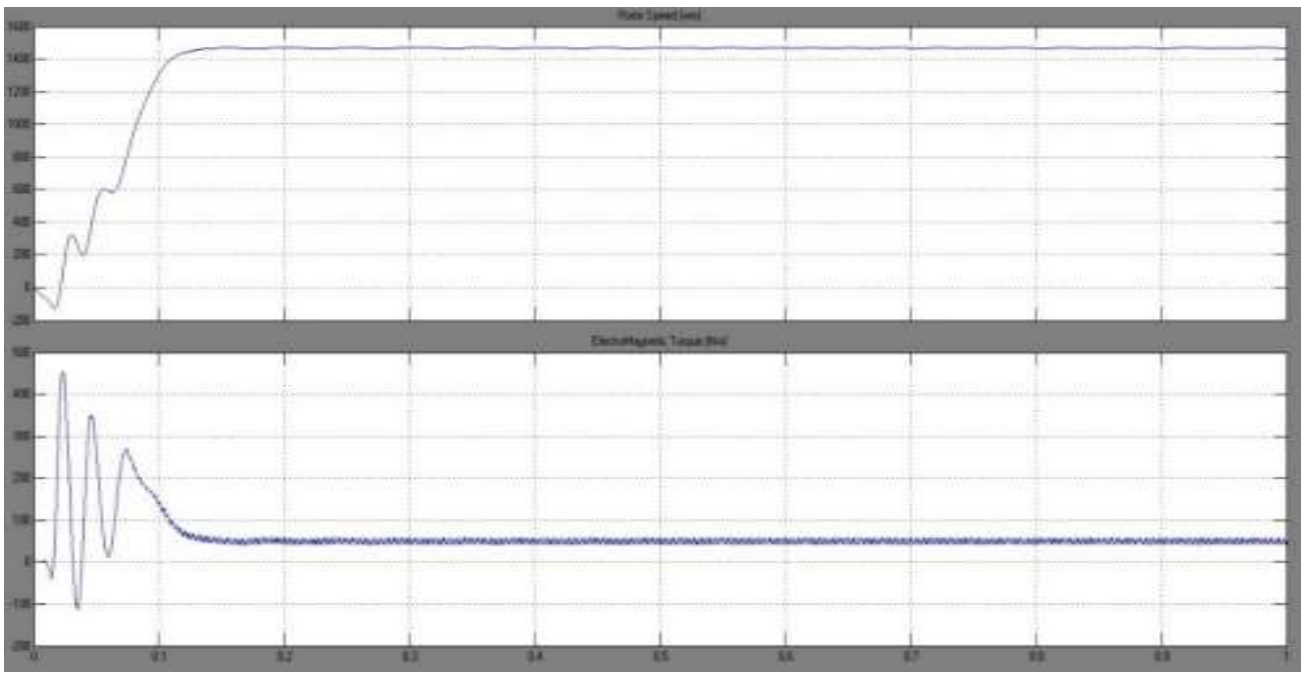

Figure 21. Speed and torque response for hybrid inverter using CO method

\subsection{Comparative Analysis}

The FFT analysis is carried out for output voltages of three phase eleven level diode clamped multilevel inverter fed induction motor and also for hybrid multilevel inverter using phase disposition, alternate phase opposition disposition and carrier overlapping modulation strategies. Comparison of performance in terms of THD is tabulated in Table 2.

Table 2. Comparison Table of Voltage THD (\%)

\begin{tabular}{cccccc}
\hline Load Torque & \multicolumn{2}{c}{ PD method } & \multicolumn{2}{c}{ APOD method } & \multicolumn{2}{c}{ CO method } \\
& $\begin{array}{c}\text { Diode clamped } \\
\text { inverter }\end{array}$ & Hybrid Inverter & $\begin{array}{c}\text { Diode clamped } \\
\text { inverter }\end{array}$ & Hybrid Inverter & $\begin{array}{c}\text { Diode clamped } \\
\text { inverter }\end{array}$ \\
\hline No-load & 8.2 & 5.86 & 8.29 & 5.9 & 12.34 \\
Half-load & 8.33 & 5.92 & 8.36 & 6.02 & 12.28 \\
Full-load & 8.37 & 6 & 8.43 & 6.04 & 12.32 \\
\hline
\end{tabular}




\begin{tabular}{|c|c|c|c|c|c|c|}
\hline \multirow[b]{2}{*}{ Load Torque } & \multicolumn{2}{|c|}{ PD method } & \multicolumn{2}{|c|}{ APOD method } & \multicolumn{2}{|c|}{ CO method } \\
\hline & $\begin{array}{l}\text { Diode clamped } \\
\text { inverter }\end{array}$ & Hybrid Inverter & $\begin{array}{l}\text { Diode clamped } \\
\text { inverter }\end{array}$ & Hybrid Inverter & $\begin{array}{l}\text { Diode clamped } \\
\text { inverter }\end{array}$ & Hybrid Inverter \\
\hline Half-load & 0.7 & 1.05 & 0.86 & 0.96 & 2.72 & 14.86 \\
\hline Full-load & 0.35 & 0.79 & 0.41 & 0.69 & 1.38 & 11.34 \\
\hline
\end{tabular}

\section{CONCLUSION}

The phase disposition, alternate phase opposition disposition and carrier overlapping sinusoidal pulse width modulation strategies have been implemented in this paper to drive the diode clamped multilevel inverter and hybrid inverter fed induction motor for eleven level output. The transition between modes in each state of hybrid inverter needs minimum commutation of switches that improves the efficiency of the inverter during switching states. The number of switches in hybrid inverter that conduct the circuit current is lower than conventional multilevel inverters i.e., diode-clamped, flying capacitor and cascaded H-bridge inverters. From the results of multicarrier based schemes, it is observed that the hybrid inverter has better performance compared to diode clamped multilevel inverter in terms of power switches that are required, control requirements and voltage THD that leads to higher reliability, reduction of converter size and cost.

\section{ACKNOWLEDGEMENTS}

We thank the Science and Engineering Research Board (SERB), Government of India, New Delhi for providing Research Project under 'Fast Track Scheme for Young Scientists' to carry out the Research on Multilevel Inverters.

\section{REFERENCES}

[1] A. Nabae, I. Takahashi, and A. Akagi, “A new neutral-point clamped PWM inverter," IEEE Trans. Ind. Appl., vol. 19, pp. 518-523, Sept./Oct. 1981.

[2] P. M. Bhagwat and V. R. Stefanovic, "Generalized structure of a multilevel PWM inverter," IEEE Trans. Industry Applications, Vol. 19, No 6, pp. 1057-1069, Nov./Dec. 1983.

[3] A. Rufer, "An aid in the teaching of multilevel inverters for high power applications," in Proc. Rec. IEEE PESC'95,pp. 347-352, 1995 .

[4] C. Newton and M. Sumner, "Multilevel converters: A real solution to medium high voltage drives?" Inst. Electron.Eng.-Power Eng. J., pp. 21-26, Feb. 1998.

[5] Jose Rodriguez, Jih-Sheng Lai and Fang Zheng Peng. "Multilevel inverters: A survey of topologies, controls and applications" IEEE Transactions on industrial electronics, Vol.49, № 4, pp.724-738, August 2002.

[6] J. S. Lai and F. Z. Peng, "Multilevel converters-A new breed of power converters," IEEE Trans. Ind. Appl.,vol. 32, no.3, pp. 509-517, May/June 1996.

[7] Xiaoming Yuanand Ivo Barb, "Fundamentals of a New Diode Clamping Multilevel Inverter", IEEE Transactions on Power Electronics, Vol.15, No.4, July 2000.

[8] P. Palanivel and S. S. Dash, "Analysis of THD and output voltage performance for cascaded multilevel inverter using carrier pulse width modulation techniques," IET Power Electron., vol. 4, no. 8, pp. 951-958, Sep. 2011.

[9] B.-M. Song, J. Kim, J.-S. Lai, K.-C. Seong, H.-J. Kim, and S.-S. Park, "A multilevel soft switching inverter with inductor coupling," IEEE Trans. Ind. Applicat., vol. 37, pp. 628-36, 2001.

[10] F. Z. Peng, "A generalized multilevel inverter topology with self voltage balancing," IEEE Trans. Ind.Applications.,vol. 37, pp. 611-618, 2001.

[11] H. Stemmler, "High power industrial drives," Proc. IEEE, vol. 82, pp.1266-1286, Aug. 1994.

[12] N. Seki and H. Uchino, "Converter configurations and switching frequency for a GTO reactive power compensator," IEEE Trans. Ind. Appl.,vol. 33, no. 4, pp. 1011-1018, Jul./Aug. 1997.

[13] A. Steimel, "Electric railway traction in europe," IEEE Ind. Appl Mag., pp. 7-17, Nov./Dec. 1996.

[14] M. D. Manjrekar, P. K. Steimer, and T. A. Lipo, "Hybrid multilevel power conversion system: a competitive solution for high-power applications," IEEETrans Ind. Applicat., vol. 36, pp. 834- 841, 2000.

[15] Susheela, P. Satish Kumar, "Performance Evaluation of Multicarrier Based Techniques for Single Phase Hybrid Multilevel Inverter using Reduced Switches", Indonesian Journal of Electrical Engineering and Computer Science, Vol. 7, No. 3, September 2017, pp. 676-686.

[16] N. Susheela, P. Satish Kumar, "Comparative Analysis of Carrier Based Techniques for Single phase Diode Clamped MLI and Hybrid Inverter with Reduced Components", Indonesian Journal of Electrical Engineering and Computer Science Vol. 7, No. 3, September 2017, pp. 687-697.

[17] Ehsan Najafi, Abdul Halim and Mohamed Yatim, "Design and Implementation of a New Multilevel Inverter Topology”, IEEE Transactions on Industrial Electronics, Vol. 59, No. 11, November 2012. 


\section{BIOGRAPHIES OF AUTHORS}
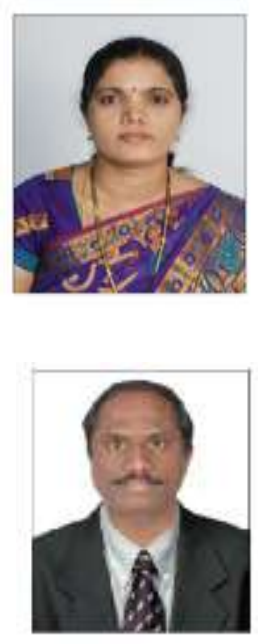

N. Susheela obtained her B.Tech degree in Electrical and Electronics Engineering in 2003 from SSJ Engineering College, JNTU and M.E degree in 2009 in Electrical Engineering with specialization of Industrial Drives and Controls from Osmania University, Hyderabad. She is pursuing Ph.D in Department of Electrical Engineering, University College of Engineering, Osmania University, Hyderabad in the area of Multilevel Inverters. She has presented papers in various journals and conferences. Since 2007 she is working as Assistant Professor in Department of Electrical Engineering, University College of Engineering (Autonomous), Osmania University, Hyderabad, Telangana, India. Her research interests include Multilevel Inverters, Special Machines and Power Electronics.

P. Satish Kumar was born in Karimnagar, Telangana, India in 1974. He obtained the B.Tech degree in Electrical and Electronics Engineering from JNTU College of Engineering, Kakinada, India in 1996. He obtained M.Tech degree in Power Electronics in 2003 and Ph.D. degree in 2011 from JNTUH, Hyderabad. He is working as Associate Professor in the Department of Electrical Engineering, University College of Engineering (Autonomous), Osmania University, Hyderabad, India. He has more than 20 years of teaching experience. His research interests include Power Electronics, Special machines, Drives and Multilevel Inverters and guiding seven research scholars. He published many papers in various international journals and conferences. He is the editorial board member of many international journals. At present, he is actively engaged in two Research Projects in the area of Multilevel inverters funded by University Grants Commission (UGC), New Delhi and Science and Engineering Research Board (SERB), New Delhi, India. 